\title{
Exkurzie v environmentálnej výchove a ich využívanie na slovenských základných školách
}

\author{
Viera Chrenščová
}

Envigogika 2012/VII/1- Recenzované články/ Reviewed Papers

Publikováno/Published 31. 05. 2012

DOI: http://dx.doi.org/10.14712/18023061.70

\begin{abstract}
Abstrakt:
Environmentálnu výchovu považujeme za proces celoživotného vzdelávania a výchovy $\mathrm{k}$ starostlivosti o životné prostredie. Účinnou realizáciou environmentálnej výchovy môžeme prispiet' k rozvíjaniu osobnostných kvalít žiakov, ktoré ich urobia schopnými chránit' a zlepšovat' životné prostredie. Proces získavania poznatkov funguje najmä na základe osobnej skúsenosti. Vo vyučovacom procese je potrebné využívat také organizačné formy, ktoré budú tento proces rešpektovat́. Podnietit́ záujem žiakov o životné prostredie a prehíbit' citovú zaangažovanost' na stave životného prostredia môžeme prostredníctvom exkurzií. v akej miere sú exkurzie využívane na slovenských základných školách sme zistovali prostredníctvom dotazníkového prieskumu, ktorého hlavným cielom bolo zistit́ názory učitel'ov na využívanie exkurzií vo vyučovacom procese s dôrazom na environmentálnu výchovu. Výskum priniesol pozitívne výsledky týkajúce využívania exkurzií vo vyučovacom procese a pri realizácii environmentálnej výchovy.
\end{abstract}

\section{Klíčová slova:}

Environmentálna výchova, exkurzie, základné školy

\begin{abstract}
:
Environmental education is a process of lifelong education and training to care for the environment. Effective implementation of environmental education can be a good tool for development of personal qualities of schoolchildren, that make them able competent to protect and improve the environment. Education is based mainly on personal experience. It is the reason why in learning process an appropriate form of education should be used. Field trips can help to stimulate the interest and the involvement of pupils on the environment. The case of this study is to explain how the field trips in environmental education on Slovak elementary schools are used. For this purpose the questionnaire survey was conducted. The aim was to investigate how teachers see the opportunity of field trips in education with an accent on environmental education. Research has brought positive results concerning the use of field trips in education and in the implementation of environmental education.
\end{abstract}

\section{Key words:}

Education, environmental education, field trip, elementary schools 


\section{Úvod}

V pedagogickom procese je vel'mi dôležitá motivácia a aktivizácia žiakov. Do vyučovania je preto potrebné zavádzat' také metódy a organizačné formy, ktoré tento proces akceptujú. Medzi organizačné formy, ktoré posilňujú motiváciu a záujem žiakov, vyznačujú sa názornostou (Skalková, 2007), dynamikou, komplexným prístupom a umožňujú žiakom aktívne sa zapájat' do vzdelávacieho procesu, patria exkurzie.

Exkurziu môžeme považovat́ za organizačnú formu, ktorá má vo vyučovacom procese didaktický význam a tiež výchovnú hodnotu. Umožňuje žiakom pozorovat́ predmety a javy, pracovný proces a jeho výsledky $v$ autentickom prírodnom, sociálnom a kultúrnom prostredí, čím získavajú správne a komplexnejšie vedomosti. Bezprostredný kontakt s poznávanou skutočnostou umocňuje zároveň u žiakov emocionálny zážitok a navodzuje citový vzt́ah k predmetu poznania. Popri poznávacej hodnote, ktorú možno považovat' za zásadnú, sa tak výrazne podielajú aj na formovaní hodnotovej orientácie žiaka (Gnoth, Pupala 2003; Petlák, 2004; Vališová, Kasíková, 2011).

Nezastupitel'ne miesto majú exkurzie v environmentálnej výchove. Sú vhodnou formou ako žiakom približit' prírodné prostredie a zdôvodnit' dôležitost' jeho ochrany. Prispievajú k prehlbovaniu, rozvíjaniu a upevňovaniu hodnotového systému v prospech konania smerom k životnému prostrediu.

Vo všeobecnosti môžeme hovorit́ o priamych a nepriamych prínosoch exkurzií (Kele, 1983) v environmentálnej výchove. Priame prínosy priamo súvisia s poznávacou funkciou. Najvýznamnejším prínosom je upevňovanie a rozširovanie teoretických vedomostí v praxi. Nepriame prínosy súvisia s výchovnou úlohou exkurzií. Vplývajú na utváranie environmentálnych návykov a zvykov environmentálneho konania a správania sa v životnom prostredí. v priebehu exkurzie je možné realizovat' praktické cvičenia, ktoré sú odporúčané aj v štátnych vzdelávacích programoch, a zároveň plnit úlohy, ktoré vyplývajú z jednotlivých zložiek výchovy: rozumovej, mravnej, telesnej, pracovnej, estetickej a kultúrnej.

Viaceré štúdie potvrdzujú, že vyučovanie mimo školy, kde zaradzujeme aj exkurzie, zvyšuje záujem žiakov o učenie (Kent et al., 1997; Lai, 1999). Pričom dlhotrvajúce exkurzie (5 dní a viac) majú na žiakov väčší vplyv ako krátkotrvajúce (Emmons, 1997; Bogner, 1998). Výrazne rozvíjajú nielen kognitívne, ale aj personálne, komunikačné a interpersonálne kompetencie žiakov.

Exkurzie, pre plnenie cielov environmentálnej výchovy (utvárat' a rozvíjat' kompetencie žiakov predovšetkým v oblasti postojov a hodnôt, viest ku komplexnému pochopeniu vzájomných vzt́ahov medzi organizmami a vzt́ahom človeka k životnému prostrediu a k potrebe prechodu k udržatel'nému rozvoju, viz ŠVP - EV_Pt 2009), je vhodné pripravovat' na miesta, kde majú žiaci možnost' poznávat' objekty živej a neživej prírody, obdivovat' krásu prírody, prírodné a kultúrne pamiatky, zamýšl'at' sa nad formovaním okolitej krajiny, nad využívaním prírodných zdrojov a nad vplyvom človeka na životné prostredie. Za takéto miesta môžeme určite označit' napr. chránené územia, náučné chodníky, jaskyne, parky a záhrady (botanické záhrady, ZOO), ekofarmy, múzeá v prírode, elektrárne, čistiarne odpadových vôd, skládky komunálneho odpadu, zberné dvory, ale aj vidiecke/mestské sídla. Ide o lokality, kde sa žiaci učia uvedomovat́ si potrebu chránit' a zároveň aj zlepšovat' životné prostredie.

Predkladaný článok predstavuje čiastkový výstup z výskumu, ktorý sa zameriaval na realizáciu environmentálnej výchovy na základných školách v SR. 


\section{Ciel’ skúmania, skúmaný súbor, použitá metóda, realizácia prieskumu}

Ciel'om skúmania bolo zistit' názory učitel'ov základných škôl v SR na využívanie exkurzií vo vyučovacom procese a exkurzií v environmentálnej výchove.

Výber respondentov bol cielený. Základný súbor tvorili učitelia základných škôl SR. Na Slovensku je 2202 základných škôl (zdroj: Ústav informácií a prognóz školstva SR, 2011). Do výskumu sa zapojilo 436 základných škôl (20 \% slovenských základných škôl). Dodržané boli tieto kritériá: typ školy (základná škola), kraj v ktorom sa škola nachádza (všetky kraje Slovenska), zriad'ovatel' (štátne, cirkevné). Dotazník vyplnil a zaslal $v$ elektronickej podobe jeden učitel' $z$ každej školy ( $n=436$ učitelov/respondentov). Zastúpení boli učitelia pre primárne vzdelávanie (72 učitel'ov) a pre nižšie sekundárne vzdelávanie (364 učitel'ov). DÍžka pedagogickej praxe učitel'ov bola rôznorodá od 2 do 45 rokov.

Pre účely prieskumu bola vybraná interogatívna metóda - dotazník, ktorý sa opieral o štandardizovanú štruktúru. Pozostával zo 14 položiek, z otázok uzavretých, polouzavretých ale aj otvorených. Otázky v dotazníku boli zamerané na exkurzie vo vyučovacom procese, realizáciu environmentálnej výchovy na ZŠ a využívanie exkurzií ako vhodnej organizačnej formy vyučovania $v$ environmentálnej výchove. Zber dát sa uskutočnil počas mesiacov január až marec v roku 2012. Dotazníky boli spracované kvantitatívne (výpočet relatívnej početnosti) a kvalitatívne prostredníctvom techniky obsahovej analýzy.

\section{Analýza a interpretácia výsledkov}

Na úvod dotazníka bola učitel'om položená otázka, prostredníctvom ktorej sme zistóvali, či učitelia zarad'ujú exkurzie ako jednu z organizačných foriem výučby do vyučovacieho procesu. Odpoved' respondentov bola pozitívna. Všetci učitelia (100 \%) vo svojej pedagogickej praxi využíva exkurzie ako jednu z organizačných foriem vyučovania.

Najčastejšieučitelia (96 \%) zarad'ujú exkurzie priamo do vyučovacieho procesu. Mimo vyučovacieho procesu ich realizuje len $5 \%$ respondentov (tab. 1 ).

Tab. 1 Čas realizácie exkurzie počas školského roka

\begin{tabular}{|l|c|}
\hline Čas realizácie exkurzie & $(\mathrm{v} \%)^{\text {Počet odpovedí }}$ \\
\hline $\begin{array}{c}\text { V rámci } \\
\text { procesu vyučovacieho }\end{array}$ & 96 \\
\hline $\begin{array}{c}\text { Mimo vyučovacieho } \\
\text { procesu }\end{array}$ & 5 \\
\hline
\end{tabular}

Z výsledkov je teda zrejme, že exkurzie majú stále zastúpenie $v$ pedagogickom procese na slovenských základných školách.

Na otázku „Majú žiaci záujem zúčastňovat' sa exkurzií počas školského roka?" sa všetci učitelia (100 \%) zhodli, že žiaci vždy vítajú tento spôsob výučby.

Učitel'om bola zároveň položená otázka "Motivujú exkurzie žiakov k získavaniu nových poznatkov a zvyšujú záujem o preberanú tému?" Až $94 \%$ učitel'ov sa zhodlo na tom, že exkurzie motivujú žiakov k získavaniu nových poznatkov a zvyšujú záujem o preberanú tému. Len $6 \%$ učitel'ov sa vyjadrilo negatívne.

Z výsledkov teda vyplýva, že exkurzie sú pre žiakov zaujímavé a motivujúce. 
Miesta, ktoré najčastejšie učitelia volia pre exkurzie, sú výstavy a múzeá (60\%). Často chodia tiež do prírody (39\%). Výrobné podniky v rámci exkurzií navštevuje so žiakmi len $10 \%$ učitel'ov (tab. 2).

Tab. 2 Miesta využívané pre exkurzie

\begin{tabular}{|l|c|}
\hline Miesto realizácie exkurzie & Počet odpovedí (v \%) \\
\hline Výstavy a múzeá & 60 \\
\hline Príroda & 39 \\
\hline Výrobné podniky & 10 \\
\hline Iné & 0 \\
\hline
\end{tabular}

Podla respondentov majú žiaci najväčší záujem o exkurzie, v ktorých poznávajú bežné prírodné, spoločenské a kultúrne prostredie $(62 \%)$. Ako d'alšie oblasti najväčšieho záujmu žiakov uvádzali exkurzie na výstavy a do múzeí (24 \%), exkurzie do škôl, vedeckých a technických ústavov (7 \%) a exkurzie do výroby s náročnejším technickým vybavením (6\%).

Väčšina učitel'ov (71 \%) využíva exkurzie najmä k doplneniu a prehíbeniu poznatkov. Pri upevňovaní učiva ich zarad'uje do vyučovania $21 \%$ pedagógov a pri sprístupňovaní učiva $7 \%$. Len $4 \%$ učitel'ov využíva exkurzie pri overovaní učiva (graf 1 ).

Graf 1 Zaradenie exkurzie do výchovno-vzdelávacieho procesu

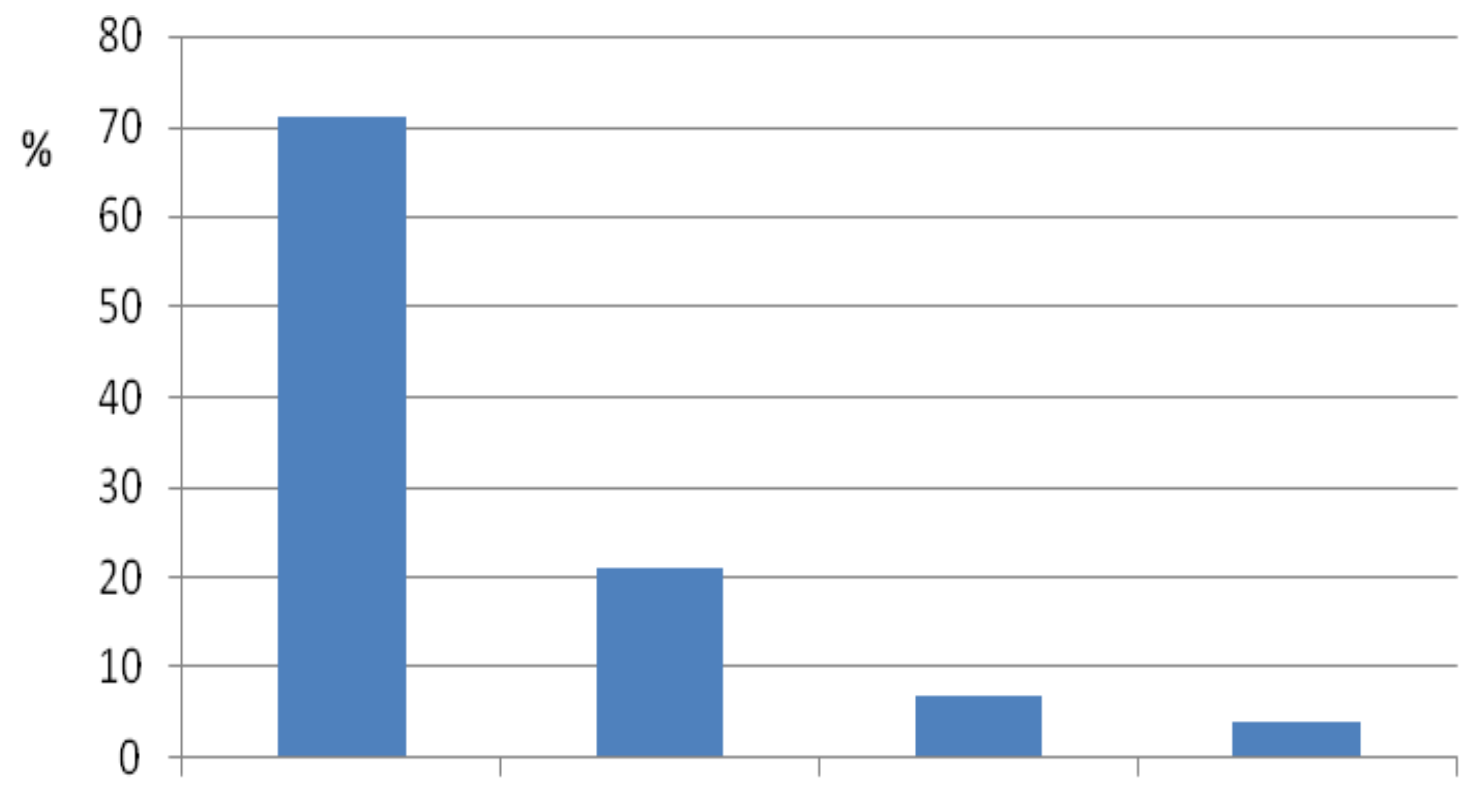

Doplňovanie Upevňovanie Sprístupňovanie Overovanie učiva poznatkov učiva novéhoučiva o preberanom

učive 
Na základe predchádzajúcich výsledkov môžeme konštatovat', že učitelia volia miesta pre exkurzie, ktoré sú vhodné nielen pre dopíňanie poznatkov o preberanom učive, ale sú pre žiakov aj prítažlivé. Zarážajúce je len malé využitie exkurzie pri sprístupňovaní učiva, ktoré je určite vždy efektívnejšie priamo v teréne ( $v$ prírodnom, spoločenskom prostredí) ako len v prostredí školy.

Pozitívne výsledky priniesla otázka, ktorej cielom bolo zistit aký typ exkurzie preferujú učitelia vo vzt́ahu k obsahu vyučovania. z odpovedí respondentov vyplynulo, že učitelia (77 \%) vo svojej pedagogickej praxi najviac preferujú komplexné medzipredmetové exkurzie, ktoré sa vztahujú na niekolko vyučovacích predmetov, čím učitelia podporujú medzipredmetové vztahy a tým sa podielajú na utváraní komplexných teoretických vedomostí a na spájaní vedomostí u žiakov z viacerých odborov do uceleného obrazu. Prednost' komplexným exkurziám, ktoré zahŕňajú štúdium viacerých aspektov jedného oboru, dáva len $14 \%$ učitel'ov, a $9 \%$ učitel'ov dáva prednost' tematickýmexkurziám zameraným na problém jedného predmetu (graf 2).

Graf 2 Preferované exkurzie učitel'mi vo vztáahu k obsahu vyučovania

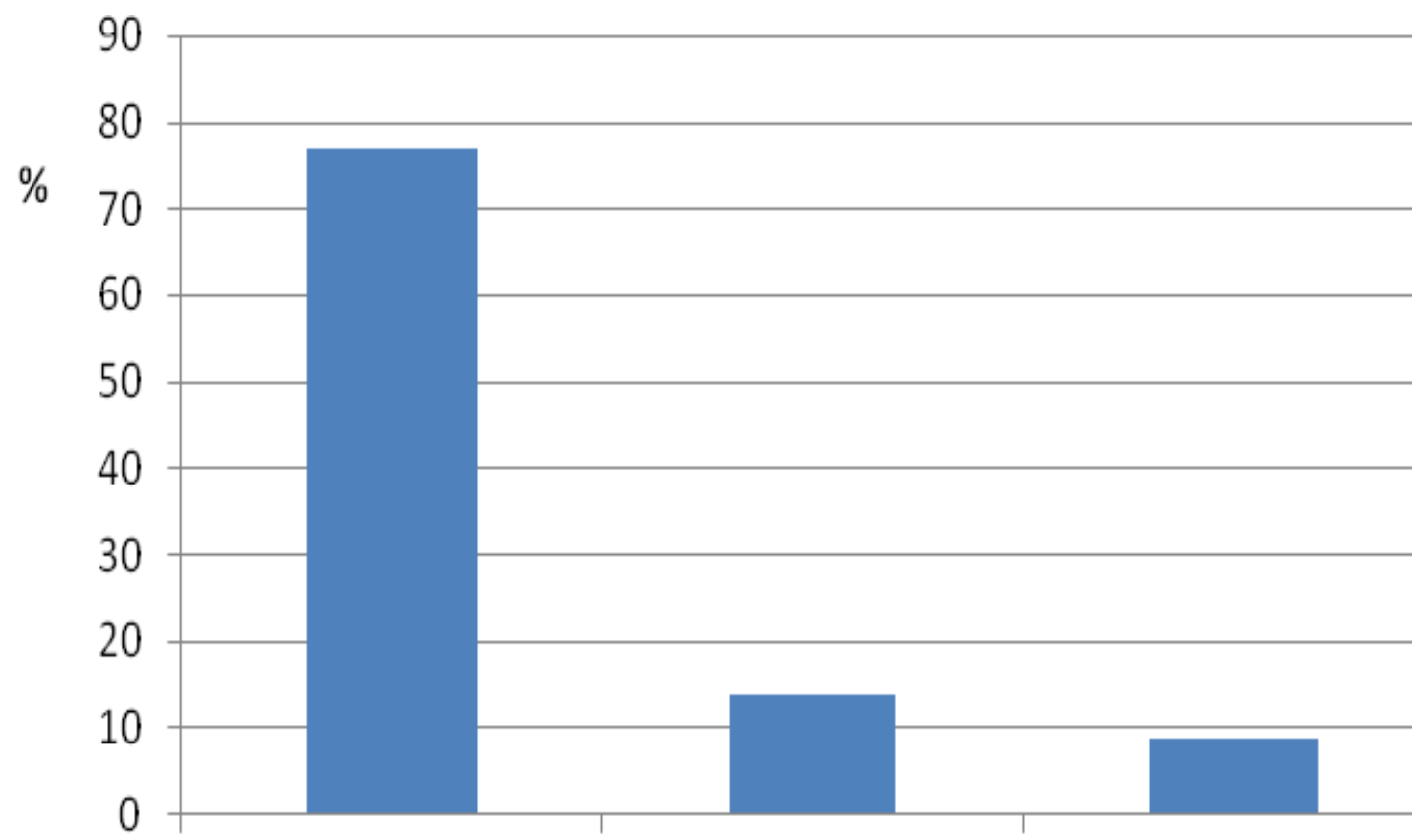

\section{Komplexné Komplexné exkurzie Tematické exkurzie} medzipredmetové

\section{exkurzie}

V rámci prieskumu sme zisttovali postavenie environmentálnej výchovy na školách a spôsoby jej realizácie, pričom sme sa sústredili na exkurzie ako vhodnú organizačnú formu pro zvyšovaní environmentálneho uvedomenia.

Zo získaných výsledkov vyplynulo, že environmentálna výchova je na základných školách najčastejšie integrovaná do iných predmetov (75 \% respondentov). Učitelia uviedli, že ju realizujú aj ako samostatný predmet (10\%), prostredníctvom školských akcií (15\%) a mimoškolských akcií (4\%). Environmentálne aktivity organizujú najmä k tematickým dňom, ako je napr. Deň Zeme, Deň vody, Deň zdravej výživy; často sa zapájajú do environmentálnych projektov napr. Zelená škola a organizujú na školách zber papiera. 
Exkurzie ako formu realizácie environmentálnej výchovy na ZŠ volí až $99 \%$ respondentov, nevyužíva ich len 1 \% učitel'ov. Environmentálne zamerané exkurzie organizujú učitelia základných škôl najčastejšie 1 x ročne (43\%) alebo 2 x do roka (23 \%). Prehl'ad d’alších odpovedí prináša tabulka 3.

Tab. 3 Počet organizovaných environmentálnych exkurzií

\begin{tabular}{|c|c|c|}
\hline $\begin{array}{cc}\text { Počet } & \text { exkurzií } \\
\text { školského roka } & \end{array}$ & počas & (v \%) ${ }^{\text {Počet odpovedí }}$ \\
\hline $1 \times$ ročne & & 43 \\
\hline $1-2$ x ročne & & 12 \\
\hline $2 \times$ ročne & & 23 \\
\hline $2-3 \times$ ročne & & 11 \\
\hline viac ako 3 x ročne & & 9 \\
\hline
\end{tabular}

Miestom, ktoré učitelia volia pre uskutočňovanie environmentálne zameranej exkurzie, je podla respondentov (99 \%) najčastejšie prírodné prostredie okolia školy, mesta alebo regiónu. Niektorí učitelia boli aj konkrétnejší a uviedli, že navštevujú chránené územia (15\%), prírodovedné múzeá (12\%), čistiarne odpadových vôd (6\%), mestské a vidiecke sídla (6\%) prostredie priemyselných podnikov (4\%), hrady a zámky (3\%), parky, zoologické a botanické záhrady (3\%), zberné dvory a skládky odpadu (2\%).

$\mathrm{Na}$ otázku „Považujete za opodstatnené využívat' exkurzie pri zvyšovaní environmentálneho uvedomenia žiakov?" až 99 \% učitel'ov skonštatovalo, že ma význam realizovat' environmentálnu výchovu formou exkurzií. Učitelia uviedli (graf 3), že environmentálne zamerané exkurzie motivujú a zvyšujú záujem žiakov o preberané učivo (85\%), o prírodu (35\%), pozitívne ovplyvňujú environmentálne konanie (zvyšuje sa záujem o triedenie odpadu, šetrenie vodou, starostlivost́ o životné prostredie) žiakov (16 $\%)$.

Graf 3 Význam exkurzií v environmentálnej výchove z pohl'adu učitel’ov 


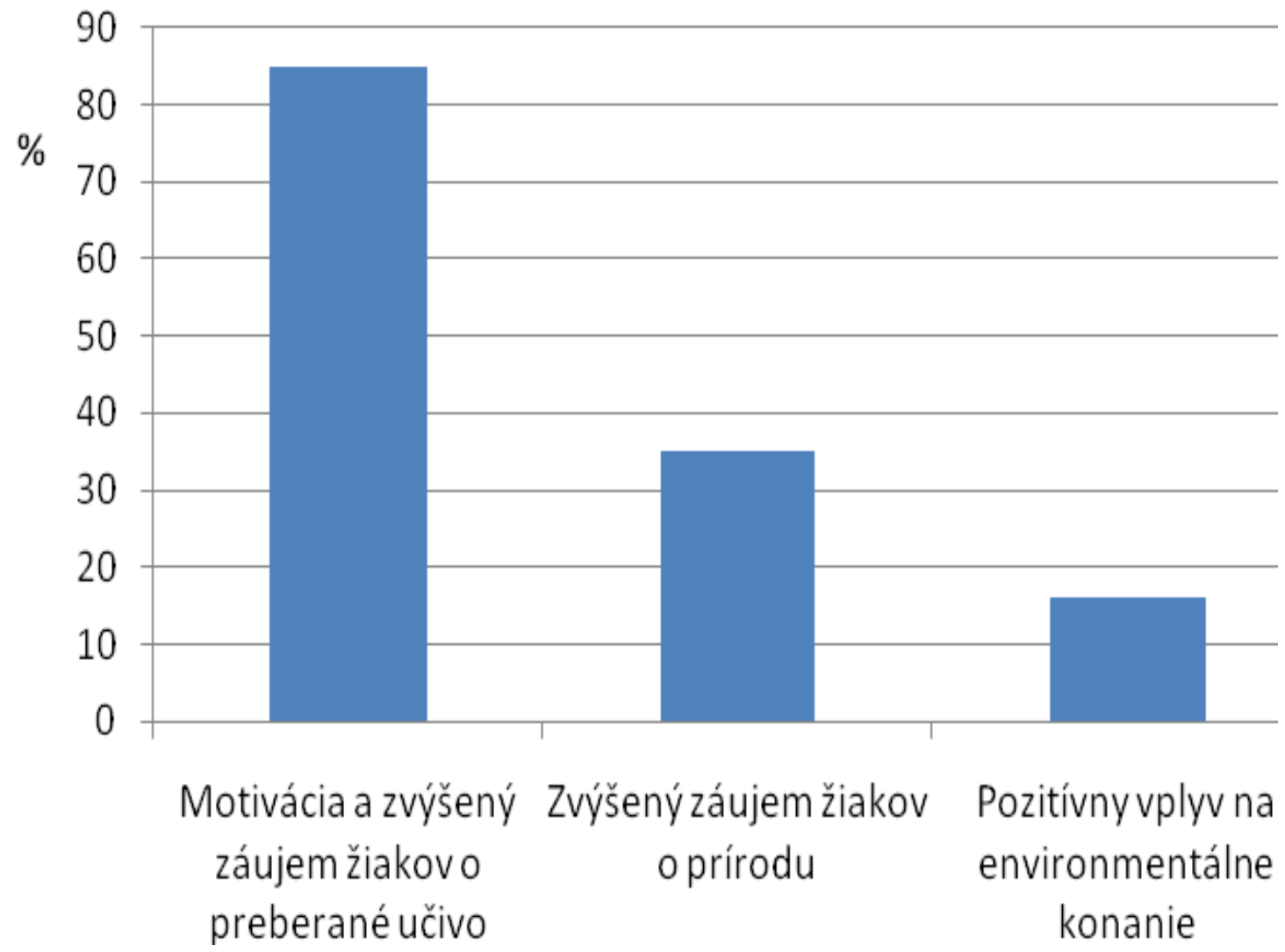

$\mathrm{Na}$ záver bola učitel’om položená otázka "S akými najčastejšími problémami sa stretávate vo svojej pedagogickej praxi v súvislosti s organizovaním exkurzií v rámci environmentálnej výchovy?" Učitelia (69 \%) sa zhodli, že najčastejšie problémy súvisia s prípravnou fázou exkurzie - finančné zabezpečenie, vyčlenenie časovej dotácie a výber vhodnej lokality. Len 30 \% učitel'ov sa vyjadrilo, že nemajú žiadne problémy.

Z predchádzajúcich výsledkov vyplýva, že i napriek organizačným t́ažkostiam učitelia považujú za opodstatnené pripravovat́ environmentálne exkurzie, pričom volia aj vhodné lokality na zvyšovanie environmentálnej uvedomelosti žiakov základných škôl.

\section{Záver}

Exkurzie sú organizačné formy vyučovania, ktoré vytvárajú velký priestor pre prepojenie teórie s praxou. Zefektívňujú tak výchovno-vzdelávací proces a tým napíňajú poslanie reformy vzdelávania na Slovensku.

Sú vhodným prostriedkom aj na realizáciu environmentálnej výchovy s využitím viacerých vyučovacích metód ako rozhovor, vysvetlovanie, demonštrácia, pozorovanie ale aj samostatná bádatel'ská, experimentálna práca jednotlivcov a skupín pri zhromažd'ovaní faktov a údajov.

Výskum medzi učitel'mi základných škôl priniesol pozitívne výsledky týkajúce využívania exkurzií vo vyučovacom procese a pri realizácii environmentálnej výchovy. Výsledky prieskumu poukázali na využívanie najmä medzipredmetových exkurzií, v rámci ktorých žiaci poznávajú bežné prírodné, spoločenské a kultúrne prostredie. Učitelia považujú exkurzie za opodstatnenú formu vzdelávania aj v environmentálnej výchove. Poukázali na ich motivačnú, poznávaciu a výchovnú funkciu. Aj napriek tomu, že často na 
učitel'a kladú zvýšené organizačné nároky a časovo sú náročné, je táto forma výučby na školách pomerne častá.

Na záver teda môžeme konštatovat', že exkurzie majú svoje miesto vo výchovnovzdelávacom procese a významne sú zastúpené aj v systéme organizačných foriem výučby environmentálnej výchovy na slovenských základných školách.

\section{Literatúra}

- Bogner, F. (1998). The influence of short-term outdoor ecology education on long-term variables of environmental perspective.. Journal of Environmental Education, 29(4), 17-29. Retrieved from http://www.tandfonline.com/doi/abs/10.1080/00958969809599124 http://dx.doi.org/10.1080/00958969809599124

- Emmons, K. M. (1997). Perceptions of the environment while exploring the outdoors:a case study in Belize. Environmental Education Research, 3(3), 327-344. Retrieved from https://www.d.umn.edu/ kgilbert/educ5165-731/pwreadings/Emmons\%20\%20Perceptions\%20of\%20the\%20Env\%20While\%20Exploring\%200utdoors.pdf

- Gnoth, M., \& Pupala, B. (2003). Vybrané kapitoly z pedagogiky I (Učitel' a vyučovací proces). Vysokoškolské skriptá. Bratislava: Prírodovedecká fakulta UK.

- Kele, F. (1983). Prínos expedícií prírodovedeckého charakteru pre rozvoj školskej geografie. Př́rodný vědy ve škole, 9(35), 356-357.

- Kemt, M., Gilbertson, D. D., \& Hunt, C. O. (1997). Fieldwork in geography teaching:A critical review of the literature and approaches. Journal of Geography in Higher Education, 21(3), 313-332.

- Lai, K. C. (1999). Freedom to learn: A study of the experiences of secondary school teachers and students in a geography field trip.. International Research in Geographical and Environmental Education, 8(3), 239-255. Retrieved from http://www.tandfonline.com/doi/abs/10.1080/10382049908667614 http://dx.doi.org/10.1080/10382049908667614

- Pytlák, E. (2004). Všeobecná didaktika. Bratislava: Iris.

- Skalková, J. (2007). Obecná didaktika 2., rozšírené a aktualizované vydanie. Praha: Grada Publishing.

- ŠVP - EV_Pt (Štátny vzdelávací program - Environmentálna výchova Prierezová téma) (2009). . Retrieved from http://www.statpedu.sk/files/documents/svp/prierezove temy/environmentalna vychova.pdf

- Vališová, A., Kasí́ková, H. (eds.), (2011). Pedagogika pro učitele. Praha: Grada Publishing.

\footnotetext{
RNDr. Viera Chrenščová, PhD., Univerzita Komenského v Bratislave, Prírodovedecká fakulta, Katedra krajinnej ekológie, Mlynská dolina, 84215 Bratislava, e-mail: chrenscova@fns.uniba.sk
} 
Časopis Envigogika vydává Centrum pro otázky životního prostředí UK. Vývoj časopisu je podpořen projektem OP VK Mezioborová sít udržitelného rozvoje.

Více najdete na internetových stránkách projektu http://mosur.czp.cuni.cz
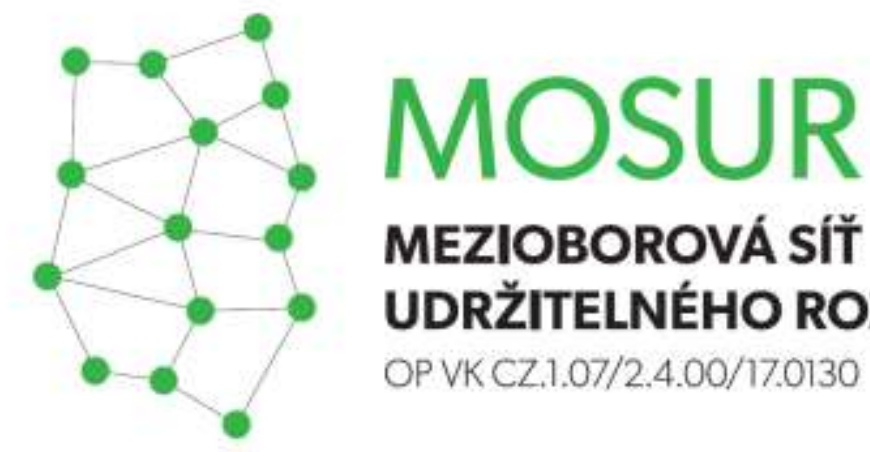

\section{MEZIOBOROVÁ SÍT}

UDRŽITELNÉHO ROZVOJE

OP VKCZ.1.07/2.4.00/17.0130
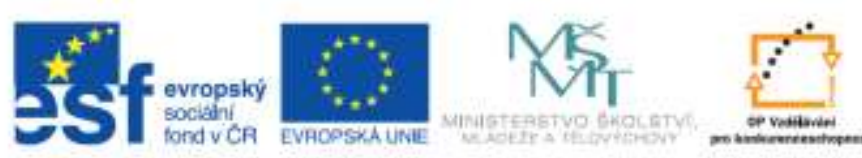

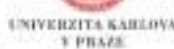

INVESTICE DO ROZVOJE VZDELAVANI 